\title{
ArcheoSciences
}

Revue d'archéométrie

\section{Investigation of ancient gold objects from Artemision at Ephesus using portable $\mu$-XRF}

Enquête sur les objets anciens en or de l'Artemision à Ephèse au moyen d'un équipement de $\mu \mathrm{FX}$ portable

Michael Melcher, Manfred Schreiner, Birgit Bühler, Andrea M. Pülz and Ulrike Muss

\section{CpenEdition}

\section{Journals}

Electronic version

URL: https://journals.openedition.org/archeosciences/2172

DOI: 10.4000/archeosciences. 2172

ISBN: 978-2-7535-1598-7

ISSN: 2104-3728

Publisher

Presses universitaires de Rennes

Printed version

Date of publication: 31 December 2009

ISBN: 978-2-7535-1181-1

ISSN: $1960-1360$

\section{Electronic reference}

Michael Melcher, Manfred Schreiner, Birgit Bühler, Andrea M. Pülz and Ulrike Muss, "Investigation of ancient gold objects from Artemision at Ephesus using portable $\mu$-XRF", ArcheoSciences [Online], 33 I 2009, Online since 10 December 2012, connection on 27 January 2022. URL: http://

journals.openedition.org/archeosciences/2172 ; DOI: https://doi.org/10.4000/archeosciences.2172 


\title{
Investigation of ancient gold objects from Artemision at Ephesus using portable $\mu-\mathrm{XRF}$
}

\author{
Enquête sur les objets anciens en or de l'Artemision à Ephèse \\ au moyen d'un équipement de $\mu F X$ portable
}

\author{
Michael Melcher*, Manfred Schreiner*, Birgit BüHLeR**, \\ Andrea M. PüLz ${ }^{* * *}$ and Ulrike Muss ${ }^{* * * *}$
}

\begin{abstract}
During two measurement campaigns in the Archaeological Museum in Istanbul and the Ephesus Museum in Selçuk, Turkey, more than 80 ancient gold objects (e.g. appliqués, statuettes and coins) from the $8^{\text {th }}-6^{\text {th }}$ centuries BC were analyzed using portable XRF instruments in order to obtain information on the chemical composition and homogeneity of the artefacts discovered during excavations in the sanctuary of Artemis at Ephesus. These results and complementary studies on the manufacturing techniques employed for making these objects will contribute to our knowledge of metalworking, trade, as well as the transfer of ideas and technologies at Ephesus and in Western Asia in the Archaic period.

The objects can be characterized as homogeneous alloys, mainly consisting of gold $(\mathrm{Au})$, silver $(\mathrm{Ag})$ and copper $(\mathrm{Cu})$. A high compositional variation of $\mathrm{Au}$ and $\mathrm{Ag}$ between different objects could be determined (Au between 48.7 and $99.9 \%$, $\mathrm{Ag}$ between $<\mathrm{detection}$ limit $(\mathrm{dl})$ and $50.9 \%$, $\mathrm{Cu}$ between $<\mathrm{dl}$ and 4.4\%).

These results demonstrated the range of gold alloys represented within the collection and allowed a discrimination between natural and artificial gold alloys (including the identification of 'refined' gold). In some cases, objects which were closely related from a typological, stylistic and/or technological point of view were also similar in composition, differing only in the sub-percent range.
\end{abstract}

Résumé : Plus de 80 objets anciens en or (p.ex. appliques, statuettes et monnaies) datés du VIIT-VI siècle av. J.-C. et trouvés lors des fouilles du sanctuaire d'Artémise à Ephèse, ont été analysés au moyen d'un équipement de FX portable pendant les deux campagnes de mesure réalisées au musée archéologique d'Istanbul et au musée d'Ephèse à Selçuk, Turquie, de façon à obtenir des informations sur leur composition chimique et sur leur homogénéité. Ces résultats, complémentés par des études sur leurs techniques de fabrication, contribuent à la connaissance du travail du métal, de son commerce, ainsi que du transfert d'idées et technologies à Ephèse et dans l'Asie de l'Ouest pendant la période Archä̈que.

Les objets ont été fabriqués avec des alliages homogènes, se composant en majorité d'or (Au), argent (Ag) et cuivre (Cu). Une forte variation de teneurs a pu être mise en évidence pour l'Au et l'Ag dans le cas de différents objets (Au entre 48,7 and 99,9\%, Ag entre < limite de détection (dl) et $509 \%$, Cu entre $<$ dl et 4,4\%).

Ces résultats montrent la gamme d'alliages d'or de la collection et permettent de discriminer entre alliages d'or naturels et artificiels (en incluant l'identification d'or "affiné"). Dans certains cas d'objets de typologie, style et/or techniques de fabrication proches, leurs compositions sont identiques, la différence n'apparaissant qu'au niveau du sous-pourcent.

Keywords: Gold, Ephesus, Artemision, XRF.

Mots-clés : Or, Éphèse, Artemision, FX.

\footnotetext{
* Institute of Science and Technology in Art-Academy of Fine Arts, Schillerplatz 3, 1010 Vienna, Austria. (m.melcher@akbild.ac.at) (m.schreiner@ akbild.ac.at)

**Vienna Institute for Archaeological Science (VIAS) - University of Vienna, Franz-Klein-Gasse 1, 1190 Vienna. (birgit.buehler@univie.ac.at)

*** Österreichisches Archäologisches Institut - Franz-Klein Gasse 1, 1190 Vienna. (andrea.puelz@oeai.at)

**** Institut für Klassische Archäologie - University of Vienna, Franz-Klein-Gasse 1, 1190 Vienna. (ulrike.muss@univie.ac.at)
} 


\section{INTRODUCTION AND HISTORICAL BACKGROUND}

About 1.500 gold objects were found in the sanctuary of the goddess Artemis at Ephesus, Turkey (Pülz, 2009). Most of these occurred in strata located under the Archaic dipteros - the so-called "Temple of Croesus" - and may thus be dated to the second half of the $7^{\text {th }}$ or the first half of the $6^{\text {th }}$ century BC (Hogarth, 1908; Bammer and Muss, 1996). Within the Archaic period, the Artemision is unique in terms of the large number and variety of gold jewellery. No other sanctuary from this period has yielded a similar wealth of gold objects. During the British and Austrian excavation campaigns at this site, a small number of figural objects, such as statuettes in human or animal form and miniature objects, were found. They were deposited in the sanctuary as votive gifts. The vast majority of gold objects, however, are dress ornaments and jewellery.

Among the gold finds, approximately 530 appliqués were found in the sanctuary of Artemis, representing at the same time the major group of artefacts (Pülz and Bühler, 2006). Most of them show holes on the edges and can therefore be addressed as garment decorations (e.g. Selçuk, inv. no. 1/71/89, Fig. 1). Because of the lack of parallels which would point to individual appliqués votive offerings in the Artemision, an interpretation of these objects as representing decorations of the cult image (Romano, 1988) or ritual garment offerings seems likely.

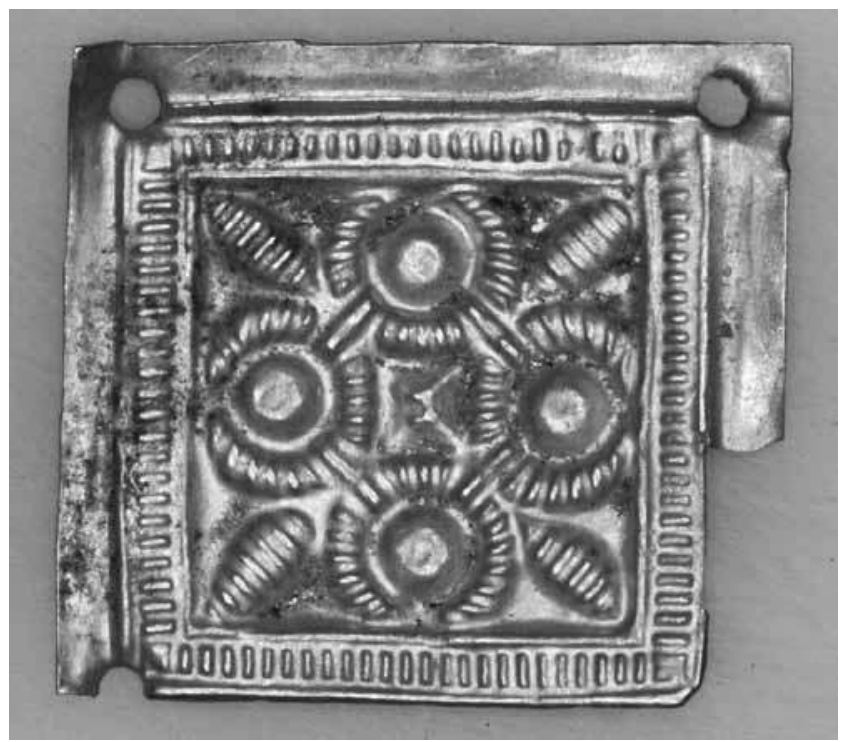

Figure 1: (See colour plate) Appliqué from the sanctuary of Artemis (Selçuk, inv. no. 1/71/89).

Figure 1: (Voir planche couleur) Appliqué du sanctuaire d'Artemise (Selçuk, inv. no. 1/71/89).
It is interesting, however, that none of the gold statuettes found in the Artemision from the $7^{\text {th }}$ or $6^{\text {th }}$ centuries BC which represent the adored goddess show garments or dresses with appliqué decorations, like later copies. A solemn figurine wears a dress whose border is decorated with meander patterns (Selçuk, inv. no. 2/59/80).

The second most important group of gold jewellery items consists of spherical and drop-shaped pendants and beads (some of which look like fruit), pins with floral heads, fibulae (predominantly of the Phrygian 'Asia Minor' type), brooches in the shape of birds of prey, and boat-shaped earrings with, in some cases, elaborate decoration (Bühler and Pülz, 2009). The vast majority of gold earrings found in the Archaic temple of Artemis at Ephesus belong to the so-called 'boat-shaped' type (sometimes also referred to as 'leech-shaped'), with a swollen body, which may be plain or decorated. Earrings of this type are very common in Western Anatolia. The best parallels for the examples from Ephesus were found in the Güre region (Özgen and Öztürk, 1996), Sardes, Lydia (Waldbaum, 1983), the Bayındır grave mound in northern Lycia (Özgen and Öztürk, 1996) and among the objects from the Norbert Schimmel Collection (Muscarella, 1974).

Most of the motifs or figurines refer to Artemis as the goddess of fertility, or her representation as the mistress of animals. For example, the bird of prey (Istanbul, inv. no. 3093, Fig. 2) is considered to be sacred to the goddess, and

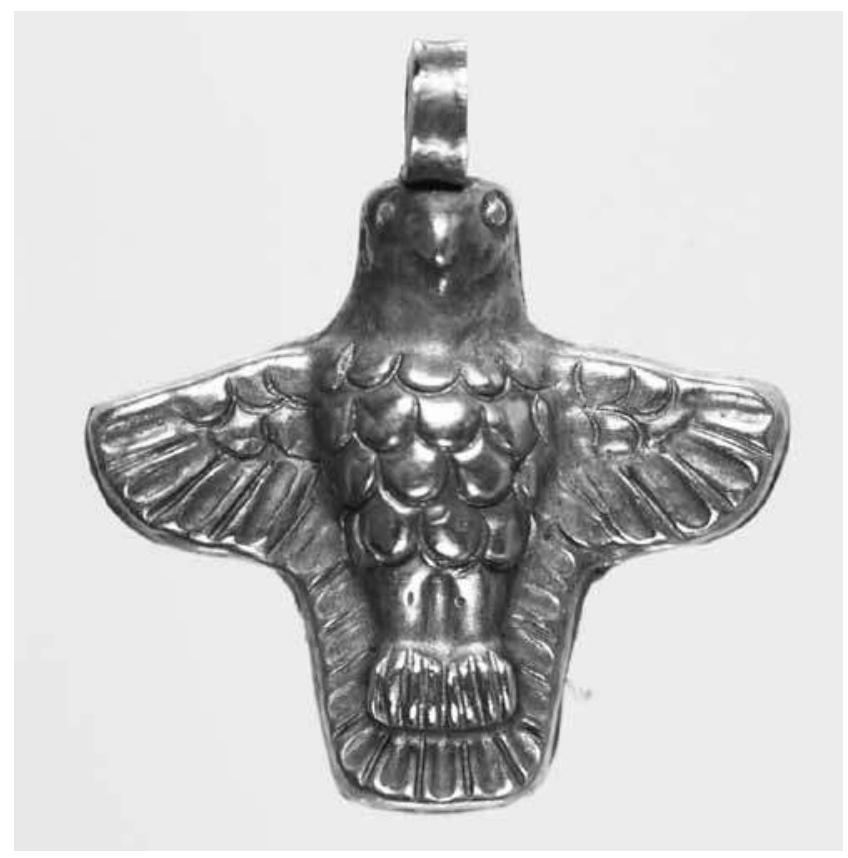

Figure 2: (See colour plate) Bird of prey (Istanbul, inv. no. 3093). Figure 2: (Voir planche couleur) Rapace (Istanbul, inv. no. 3093). 
it is found in the form of brooches, pendants or statuettes in the sanctuary (Bühler and Pülz, 2008). The bee, a symbol of reincarnation and fertility which is closely connected with the cult of Artemis, also appears in many variations, from naturalistic to very abstract forms (Pülz, 2001). Various pendants, beads and pin heads resemble fruits or seed and can therefore be interpreted as symbols of fertility. However, there are also individual finds, like a gold object in the form of a barley seed, with a real seed inside, which links it directly to the cult of Artemis.

There is no other sanctuary in the Archaic period which is, both in terms of quantity and quality, comparable to the Artemision in terms of the assemblage of gold objects. Only collections of artefacts originating from graves, especially gold jewellery from Rhodes (650-600 BC) (Laffineur, 1978), and from the Lydian Tumuli (Özgen and Öztürk, 1996) are similar in numbers. The latter, of course, are dated to a much later period (the end of the $6^{\text {th }}$ and the beginning of the $5^{\text {th }}$ century BC), but, in terms of their forms, motifs, and techniques, they strongly resemble the Ephesian finds.

When considering the artefacts found in the Artemision, it can be shown that the majority of them are related to forms indigenous to Ionia, and that they were created in local workshops. The unique fibulae decorated with a combination of lion heads and falcon heads embedded in a flower (Selçuk, inv. no. 1/43/94, Fig. 3) have no parallels

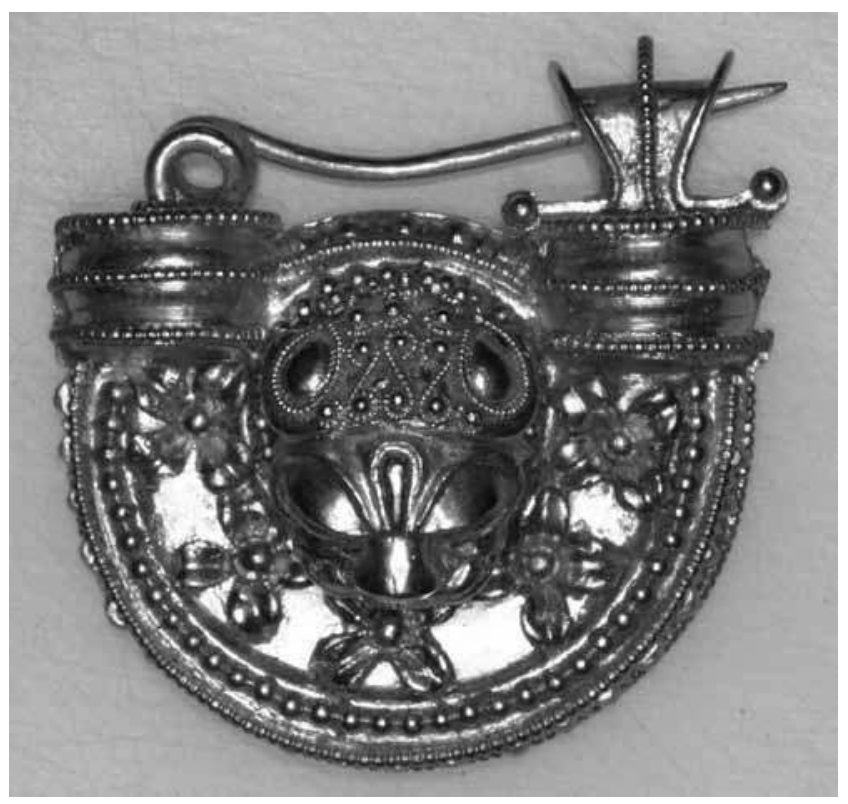

Figure 3: Fibulae decorated with a combination of lion heads and falcon heads embedded in a flower (Selçuk, inv. no. 1/43/94). Figure 3 : Fibule décorée d'une combinaison de têtes de lions et de faucons entourée de motifs floraux (Selçuk, inv. no. 1/43/94). in the Archaic world, and can therefore be addressed as a specific Ephesian product (Freiberger and Gschwantler, 2008). On the other hand, there are a few objects, such as, for example, a richly decorated head of a griffon (Selçuk, inv. no. 117/61/90) or a piece of jewellery in the form of a blossom, whose style and technology is strikingly similar to Rhodes jewellery of the Orientalizing period, so that the hypothesis of an import can be considered.

Statuettes and miniature objects (such as human extremities and small vessels) in particular were not objects intended for daily use, but designed for the purpose of giving. Through precious votive offerings, such as gold objects, one could show not only one's religious faith but also demonstrate one's status as compared to other individuals. However, votive offerings were obviously even more than that: they were also prestige objects for the recipient, that is the deity or its mortal representative (i.e. the priest), because, through precious gifts, status and power over other sanctuaries were strengthened (Godelier, 1999).

\section{MethodS}

83 of these objects, among them 11 coins, were selected for material analysis using two different self-built portable $\mathrm{X}$-ray fluorescence (XRF) instruments (henceforth referred to as XRF I and XRF II), according to the different requirements of the areas on the objects' surfaces to be analyzed. Instrument XRF I (COPRA, Compact Portable Roentgen Analyzer, Fig. 4), constructed within the EU-Project No. SMT4-CT98-2237 and used for the measurement campaign in the Istanbul Archaeological Museum, is characterized by a very small diameter (half-value width of 126 $\mu \mathrm{m}$ at $40 \mathrm{kV}, 0.4 \mathrm{~mA}, \mathrm{Fe}-\mathrm{K \alpha}$ ) of the primary X-ray beam (anode material: molybdenum), which is achieved by a polycapillary. As a result, this instrument is particularly suited for investigations of micro-domains on the surfaces of (gold) objects. A proper focusing on the desired domain is achieved by an external object positioning system (allowing for a positioning of the object with an accuracy of $0.01 \mathrm{~mm}$ in all 3 spatial directions), a microscope and a CCD-camera. For the detection of the fluorescence radiation, a drift chamber detector (Röntec X-flash L) with an energy resolution of $<170 \mathrm{eV}$ is used.

Instrument XRF II (Fig. 5), used for investigations in the Ephesus Museum in Selçuk, is equipped with a Rhodium (Rh) X-ray tube (Oxford XTF5011), a silicon drift detector (Röntec XFlash 1000), and a positioning system consisting of two laser beams (Desnica, 2005; Desnica and Schreiner, 2006). The diameter of the primary beam is approximately 


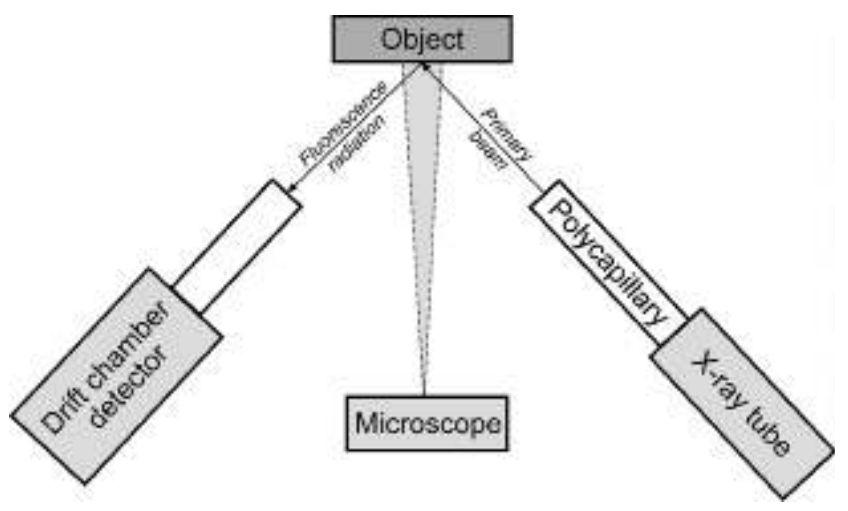

Figure 4: Scheme of the instrument XRF I used for the investigation of objects in the Archaeological Museum, Istanbul.

Figure 4: Schéma de l'équipement de FX-I utilisé dans l'étude des objets du musée archéologique d'Istanbul.

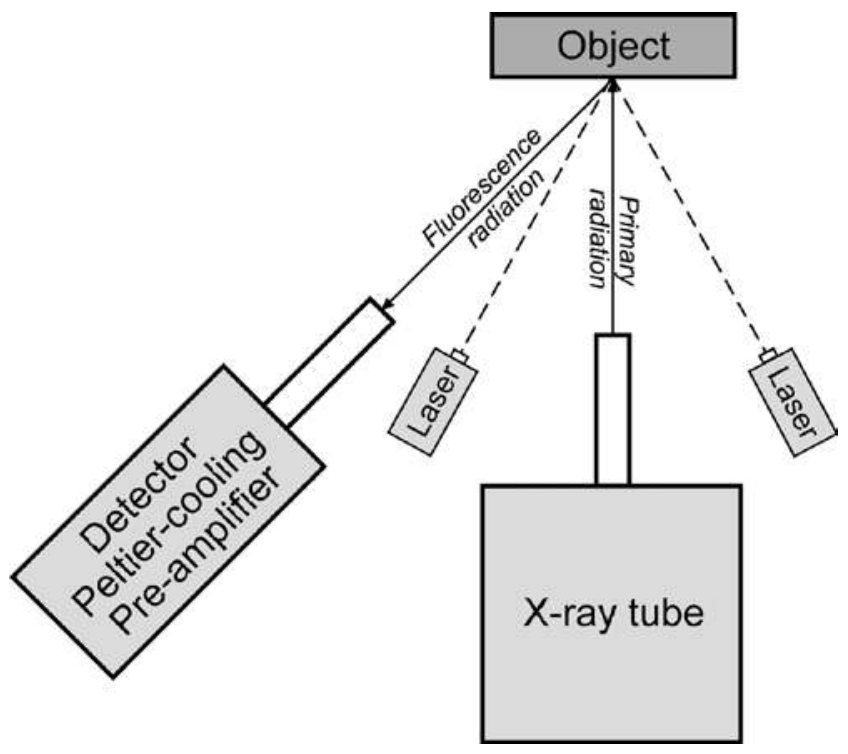

Figure 5: Scheme of the instrument XRF II used for the investigation of objects in the Ephesus Museum, Selçuk.

Figure 5: Schéma de l'équipement de FX-II utilisé dans l'étude des objets du musée d'Ephèse à Selçuk.

$1 \mathrm{~mm}$. Due to their relatively low weight, both instruments are especially suited for investigations of objects on site (i.e. in museums, collections, or near excavations) and enable a qualitative and quantitative determination of major, minor and trace elements in a non-destructive manner.

For all measurements, a tube voltage of $35 \mathrm{kV}$, a tube current of $0.8 \mathrm{~mA}$, and a measurement time of $200 \mathrm{~s}$ were used. Additionally, the tube was equipped with a $12.5 \mu \mathrm{m}$ palladium (Pd)-filter for suppression of diffraction peaks in the resulting spectrum. Typically, 3-4 measurement points were set on an object's surface. The spectra were quantified using 18 appropriate standard materials in the systems $\mathrm{Au}-\mathrm{Ag}-\mathrm{Cu}$ and $\mathrm{Ag}-\mathrm{Cu}$, as well as the software WinAxil (Win Axil X-ray Analysis Software, Canberra Benelux, Belgium). The crosschecking of the quality of the quantification in order to estimate analytical errors was carried out by the quantification of these standard materials. Relative errors of less than 3\% for the main components $\mathrm{Au}$ and $\mathrm{Ag}$ (compositional range $\geq 30 \mathrm{wt} \%$ ), and less than $20 \%$ for the minor component $\mathrm{Cu}$ (compositional range $\leq 5 \mathrm{wt} \%$ ) were verified.

\section{Results AND Discussion}

Table 1 presents the results of the analyses in tabular form. In addition to the major and minor elements $\mathrm{Au}, \mathrm{Ag}$ and $\mathrm{Cu}$, in some cases $\mathrm{Fe}$ was also detected in small amounts. As the Fe intensities also showed significant variations between different measurement points, the presence of Fe might be due to superficial contaminations of the objects. The most important result of these XRF analyses is the identification of 8 objects that were made of a gold alloy with very high Au content, of more than $97 \%$, that is of almost pure - and therefore refined - gold. Four of these objects have an $\mathrm{Au}$ content of more than $99 \%$, containing only traces of $\mathrm{Cu}$ and/or Ag: one is a cast miniature pendant in the shape of a human being (Istanbul, inv. no. 3071), while the other three objects (Istanbul, inv. nos. 3175 a, 3175 b and Selçuk, inv. no. 42/41/86) are appliqués of identical type (type b.5variant 10, according to A.M. Pülz; see e.g. Pülz and Bühler 2006). The other four objects in this group are high-quality jewellery items which consist of a large number of individual sheet-gold components and fine decorative elements (mainly granulation, in some cases also beaded wires): a brooch (Istanbul, inv. no.3157) and an earring (Istanbul, inv. no. 3033), which may have been products of the same workshop, as well as an insect-shaped miniature pendant (Istanbul, inv. no. 3087) and brooch (Istanbul, inv. no. 3088). The Au content of these four objects varies between $97.2 \%$ and $98.9 \%$, the $\mathrm{Cu}$ content between $1.1 \%$ and $2.8 \%$, and they all contain no Ag. As these four objects consist of a large number of components, it is possible that at least some of the copper detected on the surface of these objects is due to the process of reaction soldering with copper salts, which may have been used to join these components. If this assumption is correct, the actual gold content of the sheetgold components used to produce these objects may have been even higher. Significantly, all eight jewellery items with an Au content of more than $97 \%$ are products of outstanding quality. 


\begin{tabular}{|c|c|c|c|c|c|c|c|c|c|c|c|}
\hline $\begin{array}{l}\text { Object } \\
\text { inv. no. }\end{array}$ & $\mathrm{Au}$ & $\mathrm{Ag}$ & $\mathrm{Cu}$ & $\begin{array}{l}\text { Object } \\
\text { inv. no. }\end{array}$ & Au & $\mathrm{Ag}$ & $\mathrm{Cu}$ & $\begin{array}{l}\text { Object } \\
\text { inv. no. }\end{array}$ & Au & $\mathrm{Ag}$ & $\mathrm{Cu}$ \\
\hline 3175 & $99.9(0.0)$ & $0.0(0.0)$ & $0.1(0.0)$ & $105 / 30 / 77$ & $70.0(2.5)$ & $28.2(2.5)$ & $1.9(0.0)$ & $184 / 54 / 88$ & $58.0(1.5)$ & 40.5 (1.6) & $1.6(0.2)$ \\
\hline 3176 & $99.9(0.0)$ & $0.0(0.0)$ & $0.1(0.0)$ & $50 / 41 / 86$ & $68.6(0.3)$ & $28.7(0.1)$ & $2.9(0.3)$ & $8 / 41 / 86$ & $57.7(0.7)$ & $41.0(0.9)$ & $1.3(0.3)$ \\
\hline 3071 & $99.5(1.4)$ & $0.0(0.0)$ & $0.6(1.4)$ & $53 / 32 / 85$ & $68.6(3.4)$ & $29.4(3.5)$ & $2.1(0.4)$ & 3079 & $57.6(5.0)$ & $40.4(5.4)$ & $.0(0.4)$ \\
\hline $42 / 41 / 86$ & $5(0.1)$ & $0.4(0.1)$ & 0.1 & $115 / 61 / 90$ & $68.1(0.4)$ & .5) & $0.8(0.0)$ & $17 / 41 / 86$ & $57.0(1.0)$ & $41.5(1.0)$ & $6(0.1)$ \\
\hline 3157 & $9(0.7)$ & 0.0 & $1.1(0.7)$ & $2 / 93$ & $67.5(2.3)$ & $31.9(2.1)$ & $0.6(0.2)$ & $58 / 38 / 81$ & $56.6(2.6)$ & 2.4) & $.2)$ \\
\hline 3087 & $98.4(1.1)$ & $0.0(0.0)$ & $5(1.1)$ & 47 & $67.3(0.2)$ & $.0(0.3)$ & $8(0.1)$ & $9 / 68 / 89$ & $56.2(1.3)$ & $42.2(1.7)$ & $(0.4)$ \\
\hline 3033 & $3(1.7)$ & $0.0(0.0)$ & $1.7(1.7)$ & $1 / 86$ & $67.0(3.4)$ & $7(3.3)$ & $4(0.1)$ & . & 5.9) & 6.4) & $9(0.5)$ \\
\hline 3088 & $97.2(0.5)$ & $0.0(0.0)$ & 5) & 93 & 3) & 2) & .1) & 3106 & $55.3(4.4)$ & 4.4) & \\
\hline $133 / 61 / 87$ & $95.3(0.0)$ & $4.0(0.2)$ & 1) & 0a & 6 & (1) & if & $/ 80$ & 2.0) & 2.3) & .3) \\
\hline $2 / 42 / 93$ & $.7)$ & $(0.8)$ & (1.0) & 86 & 6 & ") & 1) & 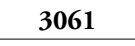 & o) & .7) & (1) \\
\hline $12 / 41 / 86$ & $92.2(1.3)$ & $6.0(0.9)$ & $(0.4)$ & $\mathbf{0 b}$ & 6 & 1 & $1.1(0.1)$ & 30 & 1.3) & $5.6(1.9)$ & $(0.6)$ \\
\hline $3 / 42 / 93$ & $91.3(2.5)$ & $4.3(0.9)$ & $4.0(1.3)$ & $13 / 42 / 93$ & $64.2(2.2)$ & 3) & .1) & 3077 & $.2)$ & 1.4) & $9(0.4)$ \\
\hline $4 / 42 / 93$ & $91.1(3.4)$ & $4.6(0.7)$ & $4.4(3.2)$ & $3 / 51 / 91$ & $62.9(0.0)$ & $.1(0.1)$ & $2.0(0.2)$ & 3118 & 2.1) & $47.8(2.0)$ & $0(0.4)$ \\
\hline $1 / 43 / 94$ & $91.0(1.0)$ & $4.8(0.5)$ & $4.3(1.1)$ & 3159 & $62.8(3.6)$ & $4.9(3.1)$ & $2.3(1.4)$ & $32 / 68 / 89$ & $50.0(0.7)$ & $46.8(0.8)$ & $2(0.2)$ \\
\hline 3084 & $84.2(2.9)$ & $14.6(3.1)$ & $1.1(0.2)$ & $38 / 68 / 89$ & $62.6(0.5)$ & $36.2(0.4)$ & $1.2(0.0)$ & $183 / 54 / 88$ & $49.0(4.7)$ & $49.6(4.1)$ & $1.4(0.8)$ \\
\hline 3083 & $84.1(2.2)$ & $14.9(2.9)$ & $0.8(0.7)$ & $50 / 32 / 85$ & $62.4(2.8)$ & $34.3(3.0)$ & $3.3(0.1)$ & $40 / 41 / 86$ & $48.7(9.8)$ & $50.9(9.7)$ & $4(0.0)$ \\
\hline $117 / 61 / 90$ & $83.4(1.4)$ & $15.4(0.5)$ & $1.2(0.9)$ & $7 / 43 / 94$ & $62.3(2.1)$ & $35.6(2.0)$ & $2.0(0.6)$ & \multicolumn{4}{|c|}{ Coins } \\
\hline 3090 & $80.6(8.7)$ & $16.0(7.4)$ & $3.4(3.2)$ & $15 / 43 / 94$ & $61.9(2.8)$ & $36.3(2.8)$ & $1.8(0.1)$ & $101 / 41 / 86$ & $83.2(4.2)$ & $15.7(4.2)$ & $1.2(0.1)$ \\
\hline $1 / 41 / 86$ & $78.7(0.6)$ & $18.5(0.3)$ & $2.9(0.9)$ & $52 / 32 / 85$ & $61.3(1.3)$ & $37.3(1.2)$ & $1.5(0.1)$ & $99 / 43 / 94$ & $66.5(7.0)$ & $31.9(7.3)$ & $1.6(0.3)$ \\
\hline $111 / 61 / 87$ & $78.1(0.8)$ & $20.3(0.7)$ & $1.7(0.1)$ & $75 / 32 / 85$ & $61.2(1.5)$ & $36.6(1.6)$ & $2.2(0.4)$ & $99 / 41 / 86$ & $64.5(1.2)$ & $34.7(1.2)$ & $0.8(0.1)$ \\
\hline $63 / 32 / 85$ & $77.5(0.2)$ & $19.9(0.4)$ & $2.6(0.2)$ & 29/51/91 & $61.2(0.7)$ & $36.1(0.6)$ & $2.8(0.1)$ & $100 / 41 / 86$ & $62.2(2.0)$ & $6.7(2.1)$ & $2(0.1)$ \\
\hline $135 / 61 / 87$ & $77.2(-)$ & $21.0(-)$ & $8(-)$ & $91 / 32 / 85$ & $60.8(3.0)$ & & $2.4(0.3)$ & $98 / 43 / 94$ & $60.7(1.3)$ & $37.7(1.2)$ & $1.7(0.1)$ \\
\hline $182 / 54 / 88$ & $74.4(0.9)$ & $23.3(1.1)$ & $2.3(0.2)$ & 3093 & $60.8(1.0)$ & $36.3(1.8)$ & $2.9(0.8)$ & $318 / 61 / 87$ & $60.7(4.4)$ & $37.0(4.1)$ & $2.4(0.5)$ \\
\hline 3076 & $74.2(7.3)$ & $24.2(7.2)$ & $1.7(0.3)$ & $174 / 38 / 81$ & $60.6(1.6)$ & $35.8(1.7)$ & $3.6(0.2)$ & $96 / 41 / 86$ & $60.6(1.9)$ & $38.4(1.7)$ & $1.1(0.2)$ \\
\hline $110 / 61 / 87$ & $73.9(0.8)$ & $24.0(1.0)$ & $2.2(0.1)$ & 3039 & $60.1(5.0)$ & $35.7(5.6)$ & $4.3(3.2)$ & $95 / 41 / 86$ & $60.5(3.2)$ & $38.3(3.2)$ & $1.2(0.0)$ \\
\hline $112 / 61 / 87$ & $72.5(0.4)$ & $25.1(0.5)$ & $2.5(0.0)$ & $6 / 19 / 81$ & $59.7(0.7)$ & $37.9(0.6)$ & $2.5(0.0)$ & $317 / 61 / 87$ & $57.1(3.8)$ & $41.1(3.4)$ & $1.8(0.4)$ \\
\hline $17 / 51 / 91$ & $71.4(3.9)$ & $27.0(3.6)$ & $1.6(0.3)$ & $1 / 71 / 89$ & $58.8(2.3)$ & $37.9(2.9)$ & $3.3(0.7)$ & $98 / 41 / 86$ & $56.4(0.3)$ & $42.1(0.3)$ & $1.6(0.0)$ \\
\hline $8 / 59 / 80$ & $70.1(1.4)$ & $27.6(1.1)$ & $2.3(0.4)$ & $10 / 43 / 94$ & $58.5(1.5)$ & $39.2(1.4)$ & $2.4(0.1)$ & $23 / 51 / 91$ & $43.4(6.8)$ & $51.1(6.9)$ & $5.6(0.1)$ \\
\hline
\end{tabular}

Table 1: Composition (average values of typically 3-4 measurements) of all 83 gold objects (72 jewellery items of different types, appliqués and statuettes, as well as 11 coins) examined in the Archaeological Museum, Istanbul and in the Ephesus Museum, Selçuk. The data are sorted by descending Au content. The numbers in brackets indicate the range (maximum value minus minimum value) observed in the single measurements. Tableau 1: Composition (teneurs moyennes de typiquement 3-4 mesures) de tous les 83 objects en or étudiés au musée archéologique d'Istanbul et dans le musée d'Éphèse à Selçuk. Les 11 derniers objets sont des monnaies. Les données sont répertoriées par valeur décroissante de la teneur en $A u$. Les valeurs entre parenthèses correspondent aux gammes (valeur maximale et valeur minimale) observées pour les mesures.

The use of gold alloys with a high gold content for the production of a number of jewellery items from the sanctuary of Artemis at Ephesus is significant because this gold was obviously refined. Considering the evidence from the gold refinery at Sardis, Lydia (see Ramage and Craddock, 2000), which is dated to "no later than the middle of the sixth century BC" (Ramage and Craddock, 2000: 95), it is possible that either the raw material (the refined gold perhaps in the form of gold bars or coins?) or the finished jewellery items were imported from Sardis. Provided this assumption is true and the date suggested for the Sardis refinery is correct, the use of refined gold could be employed as a chronological criterion, which would allow us to ascribe the objects in question to the $6^{\text {th }}$ century BC. At present, most gold objects from the sanctuary of Artemis at Ephesus are ascribed to the second half of the $7^{\text {th }}$ or the first half of the $6^{\text {th }}$ century BC. An alternative hypothesis would be that the gold was refined in Ephesian workshops. However, to date, there is no evidence available in favour of this theory, and it is not very likely that a gold refinery was active at Ephesus before the workshops recently excavated at Sardis, which provide so far the only certain evidence for the use of the cementation process (separation of silver and gold using salt) known from the ancient world. 
In this context, it is important to note that the Lydians are credited with the invention of struck coinage in the $7^{\text {th }}$ century BC, and that "the first coins were of native alluvial gold, with the composition carefully adjusted by the addition of small quantities of silver to bring the gold content down to a fixed composition, just below the minimum gold content found in the metal from the Pactolus" (Ramage and Craddock, 2000: 212-213). Analyses of Lydian coins of this type from the collections of the British Museum have shown that the majority of them contain about $54 \%$ Au (with a variation of about $2 \%$ ), $44 \% \mathrm{Ag}$ (with a variation of about $2 \%)$ and $2 \% \mathrm{Cu}$ (with a variation of $0.5 \%$ ), as well as traces of $\mathrm{Pb}$ (up to $0.2 \%$ ) and $\mathrm{Fe}$ (0.1-0.2\%) (Ramage and Craddock, 2000: 172). Two of the 'Lydian' coins from the sanctuary of Artemis at Ephesus which were analyzed in the context of the present study have a similar composition (Selçuk, inv. nos. 317/61/87 and 98/41/86), and the same is true for a considerable number of gold objects from the same site.

During the reign of the last king of Lydia, Croesus (561$547 \mathrm{BC}$ ), the first bimetallic currency system of pure gold and silver was introduced, and this required the ability to separate and refine gold and silver. All analyses of Lydian gold and silver coins have shown them to be of very high purity ( $98 \%$ or more), and gold of similar purity or higher was found on the sherds used to melt the refined metal in the Sardis workshops (Ramage and Craddock, 2000: 169174).

Although native gold usually contains silver, typically between 5 and $40 \%$, its copper content rarely exceeds $1 \%$ (Ramage and Craddock, 2000: 254). Therefore, if a gold alloy contains more than $1-2 \% \mathrm{Cu}$, it is likely to be an intentional alloy. Alluvial gold extracted from the river Pactolus varies in composition and is said to contain about $17-30 \%$ $\mathrm{Ag}$ (Ramage and Craddock, 2000: 172). The area analysis of the cross-section of a natural granule of alluvial gold found during the excavation of the Lydian gold refinery at Sardis has shown it to contain $69.6 \% \mathrm{Au}, 29.8 \% \mathrm{Ag}$ and $0.6 \%$ $\mathrm{Cu}$ (Ramage and Craddock, 2000: 148). This is particularly interesting in comparison with a gold globule (Selçuk, inv. no. 42/68/89) found in the sanctuary of Artemis at Ephesus, which contains $67.3 \% \mathrm{Au}, 32.0 \% \mathrm{Ag}$ and $0.8 \% \mathrm{Cu}$. It is thus possible that this is indeed a droplet of unrefined native gold, possibly alluvial gold from the river Pactolus or other Lydian deposits.

A number of finished gold items found in the sanctuary of Artemis at Ephesus have a similar composition, so that it is possible that they were made of unrefined native gold, possibly from Lydian deposits. Significantly, all these objects seem to be dated to the $7^{\text {th }}$ century BC. Examples of such artefacts are: a high-quality, massive human statuette produced by casting, with extensive cold-working (Selçuk, inv. no. $1 / 42 / 93-67.5 \% \mathrm{Au}, 31.9 \% \mathrm{Ag}$ and $0.6 \% \mathrm{Cu}$ ) and three fibulae of the Phrygian 'Asia Minor' type (one pair: Selçuk, inv. no. $1 / 59 / 80 \mathrm{a}-66.0 \% \mathrm{Au}, 33.0 \% \mathrm{Ag}, 1.0 \% \mathrm{Cu}$ and inv. no. $1 / 59 / 80 \mathrm{~b}-65.8 \% \mathrm{Au}, 33.2 \% \mathrm{Ag}, 1.1 \% \mathrm{Cu}$; small single fibula: Selçuk, inv. no. 115/61/90 - 68.1\% Au, 31.1\% $\mathrm{Ag}, 0.8 \% \mathrm{Cu}$ ). At least one of the coins of 'Lydian' type analyzed as part of this study (Selçuk, inv. no. 99/41/86) also belongs to this category, as it contains $64.5 \% \mathrm{Au}, 34.7 \%$ $\mathrm{Ag}$ and $0.8 \% \mathrm{Cu}$.

\section{Conclusion}

The XRF analyses presented in this study have shown that a wide range of gold alloys, both natural and intentional, were used to produce the gold objects from the temple of Artemis at Ephesus (second half of the $7^{\text {th }}-$ first half of the $6^{\text {th }}$ century BC). Significantly, the composition of these gold objects reflects important cultural and technological innovations of the period in question, such as the invention of the cementation process to achieve a complete separation of gold and silver, and the invention of coinage (first, a gold alloy with high silver content in the $7^{\text {th }}$ century $\mathrm{BC}$, then pure gold and silver coins in the $6^{\text {th }}$ century BC). As these innovations took place at Sardis (Lydia), the data provide further evidence for a strong link between the sanctuary of Artemis at Ephesus and the Kingdom of Lydia. A small number of finished gold objects, as well as a piece of workshop debris, seem to consist of unrefined native gold with $32-33 \% \mathrm{Ag}$ and approximately $1.0 \% \mathrm{Cu}$ or below. Another small group of objects was made of virtually pure (97-98\% Au or above) - and therefore refined - gold. The vast majority of objects, however, in particular most of the appliqués, have a gold content in the range of $55-70 \%$, and a copper content of more than $1.5-2.0 \%$, suggesting that they may have been alloys formed by adding additional silver (which presumably also contained some copper) to a natural, unrefined gold alloy.

\section{Acknowledgement}

The results presented in this paper were obtained during a research project financed by the Austrian Science Fund (FWF) and directed by PD Dr. Ulrike Muss. The authors also would like to thank the Turkish Department of Antiquities and Museums (Ankara) and the directors and staff of the Istanbul Archaeological Museum and the Ephesus-Museum Selçk for the permission to examine the gold objects from the Artemision at Ephesus. 


\section{References}

Bammer, A. and Muss, U., 1996. Das Artemision von Ephesos. Das Weltwunder Ioniens in archaischer und klassischer Zeit. Mainz, Verlag Philipp von Zabern.

BüHler, B. and Pülz, A.M., 2008. Typologie und Technologie der Raubvogeldarstellungen aus Gold, in U. Muss (Hrsg.), Die Archäologie der ephesischen Artemis. Gestalt und Ritual eines Heiligtums. Wien, Phoibos Verlag, 173-184.

BüHLER, B. and Pülz, A.M., 2009. Technological and typological studies on gold jewellery from the Archaic Artemision at Ephesos: the 'boat-shaped' earrings, in Archaeometallurgy in Europe: $2^{\text {nd }}$ International Conference, Aquileia, Italy, 17-21 June 2007. Milan, AIM, 377-386.

DeSNICA, V., 2005. Development, construction and application of a portable $x$-ray fluorescence device for analysis of art objects. $\mathrm{PhD}$ thesis, Vienna University of Technology, Austria.

Desnica, V. and Schreiner, M., 2006. A LabVIEW-controlled portable $x$-ray fluorescence spectrometer for the analysis of art objects. X-Ray Spectrometry 35: 280-286.

Freiberger, V. and Gschwantler, K., 2008. Goldschmiedetechnische Beobachtungen $\mathrm{zu}$ den Löwenkopffibeln aus dem Artemision von Ephesos, in U. Muss (Hrsg.), Die Archäologie der ephesischen Artemis. Gestalt und Ritual eines Heiligtums. Wien, Phoibos Verlag, 185-197.

Godelier, M., 1999. Das Rätsel der Gabe. Geld, Geschenke, heilige Objekte. München, Beck Verlag.

Hogarth, D.G., 1908. Excavations at Ephesus. The Archaic Artemisia. London, British Museum.

LafFineur, R., 1978. L'orfevrerie Rhodienne orientalisante. Paris, De Boccard.
Muscarella, O.W., 1974. Ancient Art. The Norbert Schimmel Collection. Mainz, Verlag Phillip von Zabern.

Özgen, I. and Öztürk, J., 1996. Heritage Recovered. The Lydian Treasure. Istanbul, Published by Ugur Okman for Republic of Turkey.

Pülz, A.M., 2001. Zur Interpretation von Motiven: Die Goldappliken aus dem Artemision von Ephesos, in U. Muss (Hrsg.), Der Kosmos der Artemis von Ephesos. Sonderschriften ÖAI 37. Wien, Verlag des Österreichischen Archäologischen Institutes, 221-232.

Pülz, A.M., 2009. Goldfunde aus dem Artemision von Ephesos, Forschungen in Ephesos XII/5. Wien, Verlag der Österreichischen Akademie der Wissenschaften (with a contribution from B. Bühler).

Pülz, A.M. and Bühler, B., 2006. Die Goldappliken aus dem Artemision von Ephesos. Studien zur Typologie und Technologie. Österreichische Jahreshefte 75: 229-245.

Ramage, A. and Craddock, P., 2000. King Croesus' Gold. Excavations at Sardis and the History of Gold Refining. London, British Museum Press in association with Archaeological Exploration of Sardis, Harvard University Art Museums, Monograph 11.

Romano, I.B., 1988. Early Greek cult images and cult practices, in R. Hägg, N. Marinatos, G.C. Nordquist (Hrsg.), Early Greek Cult Practice. Proceedings of the $5^{\text {th }}$ International Symposium at the Swedish Institute at Athens, 26-29 June 1986. Stockholm, P. Aströms Förlag, 127-133.

Sagona, C., 2002. Archaeology of Punic Malta. Peters ed., Leuven. Waldbaum, J.C., 1983. Metalwork from Sardis: The finds through 1974. Sardis Monographs 8. Cambridge, MA, Harvard University Press. 
